\title{
Interaksi Genotipe x Lingkungan pada Karakter dan Komponen Hasil Galur-galur Sorgum IPB
}

\section{Genotype $x$ Environment Interaction of Yield Character and Its Component of IPB Sorghum Lines}

\author{
Rentang Fajar Cakra Wibawa ${ }^{1}$, Trikoesoemaningtyas ${ }^{2 *}$, dan Desta Wirnas ${ }^{2}$ \\ 'Program Studi Pemuliaan dan Bioteknologi Tanaman, Sekolah Pascasarjana, Institut Pertanian Bogor \\ ${ }^{2}$ Departemen Agronomi dan Hortikultura, Fakultas Pertanian, Institut Pertanian Bogor \\ (IPB University), Jl. Meranti, Kampus IPB Darmaga, Bogor 16680, Indonesia
}

Diterima 13 Desember 2020/Disetujui 24 Maret 2021

\begin{abstract}
Sorghum (Sorghum bicolor (L.) Moench) is a multipurpose crop that is potential to be developed in Indonesia as food, feed, or biofuel. Brix value of stem juice and grain yield components in sorghum are the characters that need to be improved in the breeding of multipurpose sorghum varieties. This study was aimed at obtaining information on the genetic variability of stem juice Brix value, panicle traits, and yield components of sorghum breeding lines under different environmental conditions. The genetic materials used in this study were 16 sorghum breeding lines selected by pedigree and bulk methods separately from three crossing populations and 4 national sorghum varieties, grown in a randomized complete block design in two different seasons, namely the dry season of 2019 and the rainy season of 2020. The results of this study showed that the characters of grain weight per panicle and stem juice Brix value, apart from being influenced by the genotype and the environment, were also influenced by genotype $x$ environmental interactions. Correlation analysis showed that there was no significant relationship between stem juice Brix value and grain weight per panicle. Both Brix value and grain weight were positively correlated with plant height, so that tall sorghum plants tend to produce higher Brix value and grain weight per panicle. The PI 150/N-043-16-5-5-P and PI 150/K-19-6-2-B were the genotypes with higher plant height, grain weight per panicle and Brix value compared to other genotypes and were not significantly different from the national varieties of Bioguma 1, Bioguma 3, and Numbu.
\end{abstract}

Keywords: biofuel, Brix value, feed, food, grain yield

\section{ABSTRAK}

Sorgum (Sorghum bicolor (L.) Moench) merupakan tanaman multiguna yang prospektif untuk dikembangkan di Indonesia sebagai sumber pangan, pakan dan bioenergi. Nilai Brix pada nira batang dan karakter malai pada sorgum merupakan karakter hasil yang perlu diperhatikan dalam perakitan varietas sorgum multiguna. Penelitian ini bertujuan untuk memperoleh informasi keragaman nilai Brix pada nira batang dan karakter malai serta komponen hasil dari galur-galur sorgum multiguna IPB dan responnya terhadap perbedaan kondisi lingkungan. Materi genetik yang digunakan adalah 16 galur sorgum generasi $F_{7}$ hasil seleksi pedigree dan bulk secara terpisah dari tiga populasi hasil persilangan dan 4 varietas sorgum nasional, ditanam menggunakan rancangan acak kelompok di dua kondisi lingkungan yaitu musim kemarau tahun 2019 dan musim hujan tahun 2020. Hasil penelitian menunjukkan karakter hasil yaitu bobot biji per malai dan nilai Brix pada nira batang selain dipengaruhi oleh genotipe dan lingkungan, juga dipengaruhi oleh interaksi genotipe x lingkungan. Analisis korelasi menunjukkan tidak ada hubungan yang signifikan antara nilai Brix pada nira batang dengan bobot biji per malai. Masing-masing berkorelasi nyata positif dengan tinggi tanaman, sehingga sorgum yang tinggi cenderung menghasilkan bobot biji per malai dan nilai Brix yang tinggi. Genotipe PI 150/N-043-16-5-5-P dan PI 150/K-19-6-2-B merupakan genotipe dengan tinggi tanaman, bobot biji per malai dan nilai Brix yang tinggi dibanding genotipe lainnya, dan setara dengan varietas Bioguma 1, Bioguma 3, dan Numbu.

Kata kunci: bioenergi, bobot biji per malai, nilai Brix, pakan, pangan

*Penulis untuk korespondensi.e-mail: trikadytia@gmail.com 


\section{PENDAHULUAN}

Sorgum (Sorghum bicolor (L.) Moench) merupakan tanaman multiguna yang prospektif untuk dikembangkan di Indonesia sebagai bahan pangan, pakan, dan bioenergi. Sorgum yang digunakan sebagai bahan pangan mempunyai nilai gizi yang baik yaitu karbohidrat $68 \%$, lemak $2 \%$, serat pangan $10 \%$ dan protein $10 \%$, bergantung pada varietas dan lokasi penanaman (NIN, 2017). Tanaman sorgum juga mempunyai sifat stay green sehingga dapat dimanfaatkan sebagai pakan ternak (Subagio dan Aqil 2014). Batang tanaman sorgum dapat menghasilkan nira dengan kadar gula tertentu yang dapat dimanfaatkan untuk bahan baku gula cair. BPTP-Bali (2019) melaporkan bahwa dari 10 liter nira yang dihasilkan, dapat menghasilkan gula cair sebanyak 2,8 liter. Selain kandungan sukrosa, glukosa dan fruktosa, nira sorgum juga mengandung protein sebesar 1,2\% (Datta Mazumdar et al., 2012). Selain sebagai gula, nira sorgum juga dapat difermentasi menjadi biotetanol.

Perakitan varietas nasional yang multiguna merupakan upaya yang perlu dilakukan untuk menghasilkan varietas sorgum dengan karakter yang dapat dimanfaatkan, baik sebagai bahan pangan, pakan, maupun bioenergi. Karakterkarakter tersebut antara lain karakter yang berhubungan dengan biomassa, nilai Brix pada nira batang, serta karakter bijinya. Saat ini varietas yang termasuk varietas sorgum multiguna sudah dihasilkan diantaranya varietas nasional Bioguma yang mempunyai produktivitas biji, biomassa, dan nilai Brix pada nira batang yang tinggi (Balitbangtan, 2019).

Upaya pengembangan sorgum ialah dengan menghasilkan varietas nasional yang dapat dibudidayakan pada berbagai kondisi agroklimat. Pengaruh interaksi genotipe $\mathrm{x}$ lingkungan terhadap karakter-karakter hasil dan komponen hasilperlu diperhatikan untuk melihat perubahan keragaan karakter sorgum pada lingkungan yang berbeda. Interaksi genotipe $\mathrm{x}$ lingkungan dilaporkan berpengaruh terhadap sifat ketahanan terhadap penyakit karat daun (Rifka et al., 2020), biomassa sorgum (Delgado et al., 2019), dan kandungan biji sorgum seperti kandungan protein, lemak, amilosa dan tanin (Trikoesoemaningtyas et al., 2015). Kondisi lingkungan tersebut dapat berupa kondisi tanah dan musim pada saat penanaman.

Pemuliaan tanaman dengan teknik persilangan telah dilakukan oleh Departemen Agronomi dan Hortikultura, Institut Pertanian Bogor. Seleksi telah dilakukan dengan metode seleksi pedigree dan bulk secara terpisah pada tiga populasi hasil persilangan dan telah menghasilkan galurgalur harapan $\mathrm{F}_{7}$. Galur $\mathrm{F}_{7}$ hasil seleksi perlu dievaluasi karakter agronomi dan daya hasilnya serta pengaruh interaksi genotipe x lingkungan terhadap karakter-karakter tersebut sebagai persyaratan pelepasan varietas. Penelitian ini bertujuan untuk memperoleh pengetahuan tentang keragaman nilai Brix dan karakter agronomi dari galur-galur sorgum multiguna IPB dan responnya terhadap perbedaan kondisi lingkungan.

\section{BAHAN DAN METODE}

Penelitian dilaksanakan pada bulan April hingga Agustus 2019 di Kebun Percobaan Cikabayan, Fakultas Pertanian, Institut Pertanian Bogor dan bulan Januari hingga Mei 2020 di Kebun Percobaan Cikarawang, Fakultas Pertanian, Institut Pertanian Bogor. Pengamatan pascapanen dilakukan di Laboratorium Pemuliaan Tanaman 2, Departemen Agronomi dan Hortikultura, Institut Pertanian Bogor. Perbedaan kondisi iklim pada kedua percobaan tersebut terlihat pada parameter suhu minimum, kelembaban rata-rata, curah hujan rata-rata, jumlah hari hujan, dan lama penyinaran (Tabel 1).

Materi Genetik yang digunakan dalam penelitian ini adalah 8 galur F7 hasil seleksi pedigree dan 8 galur F7 hasil seleksi bulk dari persilangan tetua PI-10-90-A x Numbu, PI-150-20-A x Numbu, dan PI-150-20-A x Kawali, serta 4 genotipe pembanding, yaitu varietas Numbu, Kawali, Bioguma 1, dan Bioguma 3.

Penelitian pada masing-masing musim dilakukan menggunakan rancangan acak kelompok (RAK) satu faktor. Perlakuan terdiri dari satu faktor berupa 16 galur harapan sorgum dan empat genotipe pembanding yang diulang sebanyak tiga kali ulangan, sehingga terdapat 60 satuan percobaan. Setiap genotipe ditanam pada masing-masing satuan percobaan sebanyak 3 baris yang terdiri dari 20 tanaman dan diambil sebanyak 10 tanaman contoh pada setiap satuan percobaan.

Benih sorgum ditanam dengan jarak tanam $75 \mathrm{~cm}$ x 15 cm menggunakan sistem tugal sebanyak 2 benih per lubang. Penyulaman dilakukan pada 1 minggu setelah tanam (MST). Penjarangan dilakukan pada 2 MST sehingga hanya tersisa 1 tanaman pada setiap lubang tanam. Dosis pupuk yang digunakan adalah $150 \mathrm{~kg} \mathrm{ha}^{-1}$ Urea, $100 \mathrm{~kg} \mathrm{ha}^{-1} \mathrm{KCl}$, dan $100 \mathrm{~kg} \mathrm{ha}^{-1}$ SP-36. Pupuk KCl, SP-36 dan 2/3 dosis Urea diaplikasikan pada saat tanam dan $1 / 3$ dosis Urea diberikan pada 4 MST. Pemberian pupuk dilakukan dengan cara alur dengan jarak $\pm 10 \mathrm{~cm}$ dari lubang tanam.

Tabel 1. Perbedaan kondisi iklim dua musim tanam sorgum

\begin{tabular}{lcc}
\hline Parameter & $\begin{array}{c}\text { Musim } \\
\text { kemarau }^{\mathrm{a}}\end{array}$ & $\begin{array}{c}\text { Musim } \\
\text { hujan }^{\mathrm{b}}\end{array}$ \\
\hline Suhu minimum $\left({ }^{\circ} \mathrm{C}\right)$ & 18.0 & 21.3 \\
Suhu maksimum $\left({ }^{\circ} \mathrm{C}\right)$ & 34.1 & 34.1 \\
Suhu rata-rata $\left({ }^{\circ} \mathrm{C}\right)$ & 26.3 & 26.3 \\
Kelembaban rata-rata (\%) & 79.8 & 86.7 \\
Curah hujan rata-rata (mm) & 269.0 & 492.0 \\
Jumlah hari hujan (hari) & 11.0 & 21.0 \\
Lama penyinaran (jam) & 7.4 & 4.5 \\
\hline
\end{tabular}

Keterangan: $\mathrm{a}=$ Badan Meteorologi Klimatologi dan Geofisika (BMKG), Bogor (April-Agustus 2019), b = Badan Meteorologi Klimatologi dan Geofisika (BMKG), Bogor (Januari-Mei 2020) 
Pemeliharaan tanaman meliputi, penjarangan, penyiangan gulma, pembumbunan, dan pengendalian hama penyakit. Penjarangan dilaksanakan pada 2 MST. Penyiangan gulma dan pembumbunan dilakukan secara berkala untuk mencegah rebah pada tanaman. Penyungkupan malai sorgum dilaksanakan pada saat pengisian malai untuk melindungi malai dari hama burung. Pengendalian hama penyakit tanaman dilaksanakan menggunakan insektisida (carbofuran, deltametrin) dan fungisida (propineb).

Pengamatan dilakukan terhadap nilai Brix pada nira batang (\%) yang diukur menggunakan refraktometer pada nira yang dihasilkan dengan memotong dan memerah batang sorgum pada saat panen, serta karakter hasil dan komponen hasil, yaitu tinggi tanaman $(\mathrm{cm})$, jumlah daun (helai), diameter batang ( $\mathrm{mm}$ ), umur berbunga (hari setelah tanam/HST), umur panen (HST), panjang malai $(\mathrm{cm})$, panjang malai produktif $(\mathrm{cm})$, diameter malai $(\mathrm{mm})$, bobot malai (g), bobot biji per malai (g), dan bobot 100 butir biji (g).

Data yang diperoleh dianalisis menggunakan analisis ragam masing-masing lingkungan dan analisis ragam gabungan. Analisis ragam gabungan dilakukan pada karakter dengan ragam homogen antar lingkungan (menggunakan uji Levene) atau mempunyai nilai koefisien keragaman (KK) $<20 \%$ (Hastini et al., 2020). Apabila uji F menunjukkan pengaruh nyata pada taraf $5 \%$ atau $1 \%$ maka uji statistik selanjutnya adalah menganalisis tingkat beda nyata pada rataan galur terhadap rataan varietas pembanding dengan uji Dunnett. Selain itu data juga dianalisis menggunakan analisis korelasi gabungan dengan metode Pearson.

\section{HASIL DAN PEMBAHASAN}

Analisis ragam gabungan dapat dilakukan pada semua karakter karena mempunyai ragam yang homogen antar lingkungan atau nilai koefisien keragaman $<20 \%$ (Hastini et al., 2020), kecuali karakter bobot malai yang mempunyai ragam tidak homogen dan nilai KK $>20 \%$ (Tabel 2). Hasil analisis ragam gabungan menunjukkan bahwa genotipe berpengaruh nyata pada semua karakter yang diamati, sedangkan lingkungan dan interaksi genotipe $\times$ lingkungan berpengaruh nyata pada beberapa karakter. Koefisien keragaman lingkungan $(\mathrm{KK})$ pada penelitian ini cenderung kecil yaitu 4.38-20.54\%. Semakin besar nilai KK, menunjukkan keragaan suatu karakter lebih besar dipengaruhi oleh galat lingkungan (Delgado et al., 2019).

Berdasarkan hasil analisis ragam gabungan, nilai Brix pada nira batang yang merupakan salah satu karakter utama sorgum multiguna tidak hanya dipengaruhi oleh genotipe, tetapi juga oleh lingkungan dan interaksi genotipe dan lingkungan (Tabel 2). Perbedaan kondisi lingkungan pada penelitian ini ialah musim tanam yang berbeda. Holou dan Stevens (2012) menyatakan selain musim tanam, kondisi lingkungan yang dapat mengubah performa genotipe sorgum diantaranya ketersediaan $\mathrm{N}$ dan jenis tanah. Adanya pengaruh interaksi genotipe dan lingkungan menunjukkan selisih nilai Brix pada kedua lingkungan, tidak sama antar genotipe. Pengaruh lingkungan serta interaksi genotipe $x$ lingkungan pada nilai Brix juga dilaporkan oleh Lestari et al. (2019), Rono et al. (2016), Holou dan Stevens (2012).

Keragaman karakter terhadap komponen sumber keragaman juga ditunjukkan pada karakter-karakter komponen hasil dan karakter hasil lainnya (Tabel 2). Keragaan karakter vegetatif maupun generatif dari galurgalur ini dipengaruhi oleh genotipe. Karakter yang dipengaruhi oleh lingkungan dan interaksi genotipe $\mathrm{x}$ lingkungan hanya karakter nilai Brix pada nira batang, bobot malai, bobot biji per malai, dan bobot seratus butir. Interaksi yang nyata menunjukkan terdapat minimal satu genotipe yang mempunyai performa berbeda dibandingkan

Tabel 2. Rekapitulasi analisis ragam gabungan berbagai karakter galur-galur sorgum multiguna IPB

\begin{tabular}{|c|c|c|c|c|c|}
\hline \multirow{2}{*}{ Karakter } & \multicolumn{3}{|c|}{ Kuadrat tengah } & \multirow{2}{*}{$\mathrm{KK}(\%)$} & \multirow{2}{*}{$\begin{array}{c}\text { Nilai } \mathrm{P} \\
\text { homogenitas } \\
\text { ragam }\end{array}$} \\
\hline & $\operatorname{Musim}(\mathrm{M})$ & Genotipe (G) & GxM & & \\
\hline Nilai Brix pada nira & $934.90 * *$ & $15.02 * *$ & $19.49 * *$ & 19.73 & 0.361 \\
\hline Tinggi tanaman & $80,639.28 * *$ & $5,754.76^{* *}$ & $339.04 \mathrm{tn}$ & 7.09 & 0.374 \\
\hline Diameter batang & $40.82 \mathrm{tn}$ & $9.64 * *$ & $4.44 \mathrm{tn}$ & 10.01 & 0.001 \\
\hline Jumlah daun & $4.79 \operatorname{tn}$ & $3.57 * *$ & $1.32 * *$ & 5.48 & 0.009 \\
\hline Umur berbunga & $24.30 \mathrm{tn}$ & $55.50 * *$ & 8.16 tn & 4.87 & 0.001 \\
\hline Umur panen & $45.63 \mathrm{tn}$ & $54.52 * *$ & $12.83 \mathrm{tn}$ & 4.38 & 0.003 \\
\hline Panjang malai & $126.80 \mathrm{tn}$ & $19.61 * *$ & $1.93 \mathrm{tn}$ & 6.47 & 0.204 \\
\hline Panjang malai produktif & $155.23^{*}$ & $13.83 * *$ & $1.76 \mathrm{tn}$ & 7.53 & 0.132 \\
\hline Diameter malai & $5,518.34 * *$ & $83.32 * *$ & $57.12 \mathrm{tn}$ & 10.60 & 0.595 \\
\hline Bobot malai & $120,460.90 * *$ & $375.28 *$ & $323.46^{*}$ & 20.54 & 0.003 \\
\hline Bobot biji per malai & $103,062.21 * *$ & $255.76^{* *}$ & $262.54 * *$ & 18.26 & 0.001 \\
\hline Bobot seratus butir & $54.81 * *$ & $1.28 * *$ & $0.30 * *$ & 12.57 & 0.455 \\
\hline
\end{tabular}

Keterangan: $*=$ berpengaruh nyata pada taraf $5 \%$; ** = berpengaruh nyata pada taraf $1 \%$; tn $=$ tidak berpengaruh nyata; KK $=$ koefisien keragaman 
genotipe lain. Pengaruh lingkungan serta interaksi genotipe $\times$ lingkungan pada berbagai karakter sorgum telah dilaporkan oleh Lestari et al. (2019), Carcedo et al. (2017), Rono et al. (2016) dan Amare et al. (2015), yang menunjukkan keragaman berbagai karakter, bergantung pada genotipe yang digunakan dan lingkungan tumbuhnya.

Uji lanjut Dunnett terhadap karakter komponen hasil pada Tabel 3 menunjukkan terdapat keragaman performa antar masing-masing galur terhadap varietas pembanding. Galur PI 150/N-043-16-5-5-P dan PI 150/K-19-6-2-B mempunyai karakter tinggi tanaman, diameter batang, jumlah daun, panjang malai, dan diameter malai yang tidak berbeda nyata dibanding varietas nasional antara lain Bioguma 1, Bioguma 3, dan Numbu. Kedua galur tersebut mempunyai karakter bobot 100 butir biji yang berbeda nyata lebih kecil dibanding varietas nasional sebagai pembanding.

Nilai Brix pada nira batang merupakan karakter penting yang harus ada di dalam varietas sorgum multiguna. Penelitian ini menunjukkan bahwa karakter tersebut beragam pada setiap genotipe dan dipengaruhi oleh lingkungan tumbuhnya (Tabel 4). Genotipe PI 10/N-18-12-7-B dan PI 10/N-324-2-15-2-P mengalami peningkatan nilai Brix berturut-turut sebesar 10.11 dan 10.31\% (Tabel 4). Varietas Bioguma 1, Bioguma 3, dan Numbu juga mengalami peningkatan nilai Brix berturut-turut sebesar 9.02, 6.63, dan $4.13 \%$. Hal tersebut menunjukkan bahwa genotipe PI 10/N18-12-7-B dan PI 10/N-324-2-15-2-P lebih peka terhadap perubahan lingkungan dibanding varietas pembanding. Informasi stabilitas dan adaptabilitas suatu genotipe dapat dijadikan landasan untuk perbaikan varietas sorgum ke depan (Hamidou et al., 2018). Selain itu informasi tersebut juga dapat digunakan untuk membuat rekomendasi pelepasan varietas (Admas dan Tesfaye, 2017).

Morey et al. (2018) menyatakan persamaan MTEY (Maximum Theoretical Ethanol Yield) lebih baik dalam menguji performa suatu genotipe dalam menghasilkan bioetanol, yaitu dengan memperhatikan nilai Brix dan hasil nira. Rono et al. (2018) menyatakan bahwa volume atau hasil nira batang dan rendemen gula merupakan penentu besarnya bioetanol yang mungkin dihasilkan. Oleh karena itu, selain nilai Brix, volume nira dan rendemen gula juga merupakan variabel yang perlu diperhatikan dalam perakitan varietas sorgum multiguna.

Karakter bobot biji per malai juga dipengaruhi oleh interaksi genotipe $\mathrm{x}$ lingkungan. Curah hujan diduga menjadi salah satu faktor utama yang berpengaruh dalam perbedaan respon masing-masing genotipe (Ndiaye et al., 2019). Genotipe PI 10/N-21-14-3-B, PI 150/N-182-5-12-7-

Tabel 3. Rerata genotipe beberapa karakter galur-galur sorgum multiguna IPB di dua musim tanam

\begin{tabular}{|c|c|c|c|c|c|c|}
\hline Genotipe & TT & DBT & JDA & PMA & DMA & BSB \\
\hline PI 10/N-094-4-12-7-P & 211.94abcd & 17.96 & $12.97 \mathrm{~d}$ & $20.38 \mathrm{c}$ & 54.24 & $1.84 \mathrm{abd}$ \\
\hline PI 10/N-18-12-7-B & 231.03abcd & $18.59 \mathrm{c}$ & 14.35 & $21.68 \mathrm{c}$ & $51.56 \mathrm{~d}$ & $2.41 \mathrm{abd}$ \\
\hline PI 10/N-21-14-3-B & 198.49abd & $21.32 \mathrm{abc}$ & $15.24 \mathrm{ac}$ & $22.10 \mathrm{~b}$ & 57.44 & $1.93 \mathrm{abd}$ \\
\hline PI 10/N-324-2-15-2-P & $221.74 \mathrm{abcd}$ & $18.20 \mathrm{c}$ & 13.42 & $17.61 \mathrm{c}$ & 59.08 & $2.00 \mathrm{abd}$ \\
\hline PI 150/N-043-16-5-5-P & $251.44 \mathrm{c}$ & $18.64 \mathrm{c}$ & 14.42 & $20.24 \mathrm{c}$ & $60.32 c$ & $2.24 \mathrm{abd}$ \\
\hline PI 150/N-043-6-9-5-P & 169.96abd & 17.27 & 13.35 & 22.91abd & 56.95 & $2.58 \mathrm{bcd}$ \\
\hline PI 150/N-15-25-3-B & 198.66abd & 16.12 & $12.97 \mathrm{~d}$ & $20.82 \mathrm{c}$ & 54.37 & $2.50 \mathrm{abcd}$ \\
\hline PI 150/N-182-5-12-7-P & 206.01abd & 17.34 & 13.68 & $20.21 \mathrm{c}$ & 59.39 & $2.75 \mathrm{abcd}$ \\
\hline PI 150/N-4-6-7-B & $201.12 \mathrm{abd}$ & 16.62 & 13.17 & $19.61 \mathrm{c}$ & 54.09 & $2.62 \mathrm{abcd}$ \\
\hline PI 150/K-1-4-1-B & 220.71abcd & 17.59 & 13.92 & 23.08abd & $50.50 \mathrm{bd}$ & $2.36 \mathrm{abd}$ \\
\hline PI 150/K-19-6-2-B & $247.75 c$ & 16.81 & 13.28 & $21.55 \mathrm{c}$ & 56.18 & $2.56 \mathrm{abcd}$ \\
\hline PI 150/K-20-1-5-B & 208.16abd & $18.21 \mathrm{c}$ & 13.75 & $25.51 \mathrm{abd}$ & 57.98 & $2.70 \mathrm{abcd}$ \\
\hline PI 150/K-248-16-5-3-P & $223.81 \mathrm{abcd}$ & 16.92 & 13.75 & $20.78 \mathrm{c}$ & $51.80 \mathrm{~d}$ & $2.70 \mathrm{abcd}$ \\
\hline PI 150/K-374-7-1-1-P & $240.65 \mathrm{acd}$ & 17.06 & 14.43 & $21.19 \mathrm{c}$ & 58.58 & $2.26 \mathrm{abd}$ \\
\hline PI 150/K-375-17-1-5-P & $194.30 \mathrm{abd}$ & $18.17 \mathrm{c}$ & $15.55 \mathrm{abc}$ & $21.15 \mathrm{c}$ & 54.58 & $2.24 \mathrm{abd}$ \\
\hline PI $150 / K-8-2-8-B$ & 165.35abd & 17.71 & $15.43 \mathrm{abc}$ & $19.84 \mathrm{c}$ & $52.79 \mathrm{~d}$ & $2.38 \mathrm{abd}$ \\
\hline Bioguma 1 (a) & 270.27 & 16.72 & 13.78 & 19.79 & 57.68 & 3.28 \\
\hline Bioguma 3 (b) & 264.02 & 17.14 & 13.95 & 19.68 & 61.60 & 3.45 \\
\hline Kawali (c) & 183.05 & 15.00 & 13.47 & 24.34 & 50.04 & 1.89 \\
\hline Numbu (d) & 267.64 & 18.58 & 14.43 & 19.9 & 63.21 & 3.38 \\
\hline
\end{tabular}

Keterangan: TT = tinggi tanaman $(\mathrm{cm}) ; \mathrm{DBT}=$ diameter batang $(\mathrm{mm}) ; \mathrm{JDA}=$ jumlah daun (helai); PMA = panjang malai $(\mathrm{cm}) ; \mathrm{DMA}=$ diameter malai (mm); BSB = bobot seratus butir biji (g). Angka yang diikuti huruf a, b, c, atau d menunjukkan berbeda nyata terhadap genotipe pembanding Bioguma 1 (a), Bioguma 3 (b), Kawali (c), atau Numbu (d) menurut uji Dunnett pada taraf $5 \%$ 
Wibawa et al. / J. Agron. Indonesia 49(1):37-44

Tabel 4. Rerata nilai Brix (\%) pada nira batang galur-galur sorgum multiguna IPB

\begin{tabular}{lccc}
\hline Genotipe & Musim kemarau & Musim hujan & Rerata genotipe \\
\hline PI 10/N-094-4-12-7-P & 5.23 & $12.40 \mathrm{c}$ & 8.82 \\
PI 10/N-18-12-7-B & 5.17 & $15.28 \mathrm{c}$ & 10.22 \\
PI 10/N-21-14-3-B & 6.38 & $11.04 \mathrm{a}$ & 8.71 \\
PI 10/N-324-2-15-2-P & 5.16 & $15.47 \mathrm{c}$ & 10.32 \\
PI 150/N-043-16-5-5-P & 5.38 & $13.67 \mathrm{c}$ & 9.52 \\
PI 150/N-043-6-9-5-P & 4.94 & $4.73 \mathrm{abd}$ & $4.84 \mathrm{abcd}$ \\
PI 150/N-15-25-3-B & 5.69 & $10.54 \mathrm{a}$ & 8.12 \\
PI 150/N-182-5-12-7-P & $4.16 \mathrm{c}$ & $11.13 \mathrm{a}$ & $7.65 \mathrm{a}$ \\
PI 150/N-4-6-7-B & $3.80 \mathrm{c}$ & $12.07 \mathrm{c}$ & 7.94 \\
PI 150/K-1-4-1-B & $3.64 \mathrm{c}$ & $12.00 \mathrm{c}$ & 7.82 \\
PI 150/K-19-6-2-B & 6.40 & $12.19 \mathrm{c}$ & 9.29 \\
PI 150/K-20-1-5-B & $4.67 \mathrm{abd}$ & $5.85 \mathrm{abd}$ \\
PI 150/K-248-16-5-3-P & 7.03 & $13.53 \mathrm{c}$ & 10.15 \\
PI 150/K-374-7-1-1-P & 6.76 & $12.67 \mathrm{c}$ & 10.89 \\
PI 150/K-375-17-1-5-P & 9.10 & $12.13 \mathrm{c}$ & 8.72 \\
PI 150/K-8-2-8-B & 5.30 & $9.27 \mathrm{a}$ & $7.66 \mathrm{a}$ \\
Bioguma 1 (a) & 6.06 & 15.20 & 10.69 \\
Bioguma 3 (b) & 6.18 & 12.80 & 9.48 \\
Kawali (c) & 6.17 & 7.87 & 8.70 \\
Numbu (d) & 9.52 & 12.53 & 10.47 \\
\hline
\end{tabular}

Keterangan: Angka yang diikuti huruf a, b, c, dan/atau d menunjukkan berbeda nyata terhadap genotipe pembanding Bioguma 1 (a), Bioguma 3 (b), Kawali (c), dan/atau Numbu (d) menurut uji Dunnett pada taraf 5\%.

P, dan PI 150/K-20-1-5-B mempunyai karakter bobot biji per malai yang tidak berbeda nyata dibandingkan varietas Bioguma 1, Bioguma 3, dan Numbu. Genotipe-genotipe tersebut mengalami peningkatan bobot biji per malai 67.09 g hingga 90.27 g pada musim tanam yang berbeda (Tabel 5). Trikoesoemaningtyas et al. (2017) menyatakan karakter bobot biji per malai diketahui dikendalikan oleh aksi gen epistasis. Keragaan karakter yang dikendalikan oleh gen epistasis sangat bergantung pada kondisi lingkungan (de Vos et al., 2013). Interaksi gen epistasis dan lingkungan (GxGxE) berdampak pada sifat/karakter yang kompleks dan dapat bersifat dinamis (Kerwin et al., 2017). Keragaman karakter bobot biji per malai cenderung tinggi bergantung pada kondisi lingkungan penanaman.

Analisis korelasi pada Gambar 1 menunjukkan bahwa masing-masing karakter mempunyai keeratan hubungan yang beragam. Nilai Brix pada nira dan bobot malai yang merupakan karakter utama dalam sorgum multiguna mempunyai korelasi nyata positif terhadap tinggi tanaman, dengan koefisien korelasi berturut-turut sebesar 0.71 dan 0.52. Oleh karena itu genotipe dengan bobot biji per malai dan nilai Brix yang tinggi cenderung dihasilkan dari genotipe dengan tinggi tanaman yang tinggi. Genotipe PI 150/N-043-16-5-5-P dan PI 150/K-19-6-2-B merupakan genotipe dengan tinggi tanaman yang tinggi dan cenderung mempunyai karakter bobot biji per malai dan nilai Brix yang tinggi dibanding genotipe lain serta tidak berbeda nyata dibanding varietas Bioguma 1, Bioguma 3, dan Numbu.

Nilai Brix pada nira batang hanya berkorelasi nyata positif terhadap tinggi tanaman dan berkorelasi nyata negatif terhadap panjang malai (Gambar 1). Meskipun demikian menurut Shukla et al. (2017), tanaman sorgum tidak harus tinggi untuk menghasilkan akumulasi gula yang tinggi. Hasil analisis korelasi juga menunjukkan nilai Brix tidak berkorelasi nyata terhadap karakter lain yang diamati, diantaranya karakter bobot biji per malai. Hasil yang berbeda ditunjukkan pada penelitian Makanda (2017), yang menyatakan bahwa nilai Brix pada nira batang berkorelasi nyata positif terhadap hasil biji, tetapi mempunyai pengaruh langsung yang nyata negatif. Selain itu, Erickson et al. (2011) dalam penelitiannya menunjukkan nilai Brix yang rendah cenderung berhubungan dengan produksi biomassa segar yang lebih besar. Oleh karena itu pertimbangan kriteria seleksi menjadi sangat penting untuk mencapai tujuan perakitan varietas, karena beberapa karakter cenderung mempunyai keeratan hubungan yang negatif terhadap karakter lain. Oyier et al. (2017) juga menyatakan bahwa periode panen berpengaruh terhadap hasil biji dan nira, yaitu semakin mencapai masak fisiologis semakin tinggi hasil bijinya, tetapi hasil nira justru menurun. Periode panen terbaik adalah saat biji sudah mulai mengeras, yaitu sekitar 28-35 hari setelah antesis (Oyier et al., 2017). 
Tabel 5. Rerata bobot biji per malai (g) galur-galur sorgum multiguna IPB

\begin{tabular}{|c|c|c|c|}
\hline Genotipe & Musim kemarau & Musim hujan & Rerata genotipe \\
\hline PI 10/N-094-4-12-7-P & 24.78 & 61.08abd & $42.93 \mathrm{bd}$ \\
\hline PI 10/N-18-12-7-B & 19.72 & $64.85 \mathrm{abd}$ & $42.29 \mathrm{bd}$ \\
\hline PI 10/N-21-14-3-B & 14.38 & $104.65 \mathrm{c}$ & $59.51 \mathrm{c}$ \\
\hline PI 10/N-324-2-15-2-P & 19.95 & $69.82 \mathrm{bd}$ & $44.88 \mathrm{bd}$ \\
\hline PI 150/N-043-16-5-5-P & 26.86 & 76.19 & 51.53 \\
\hline PI 150/N-043-6-9-5-P & 19.43 & 75.35 & $47.39 d$ \\
\hline PI 150/N-15-25-3-B & 17.89 & 79.67 & 48.78 \\
\hline PI 150/N-182-5-12-7-P & 21.19 & 89.70 & 55.45 \\
\hline PI 150/N-4-6-7-B & 18.58 & 77.77 & 48.17 \\
\hline PI 150/K-1-4-1-B & 17.97 & $71.77 \mathrm{bd}$ & $44.87 \mathrm{bd}$ \\
\hline PI 150/K-19-6-2-B & 24.75 & 76.48 & 50.62 \\
\hline PI 150/K-20-1-5-B & 17.12 & 93.33 & 55.22 \\
\hline PI 150/K-248-16-5-3-P & 26.61 & 74.98 & 50.80 \\
\hline PI 150/K-374-7-1-1-P & 22.04 & 76.84 & 49.44 \\
\hline PI 150/K-375-17-1-5-P & 29.88 & $68.53 \mathrm{bd}$ & 49.21 \\
\hline PI 150/K-8-2-8-B & 16.68 & 74.80 & $45.74 \mathrm{bd}$ \\
\hline Bioguma 1 (a) & 23.39 & 90.48 & 56.93 \\
\hline Bioguma 3 (b) & 26.77 & 99.50 & 63.14 \\
\hline Kawali (c) & 10.44 & 72.75 & 41.60 \\
\hline Numbu (d) & 27.46 & 99.55 & 63.50 \\
\hline
\end{tabular}

Keterangan: Angka yang diikuti huruf a, b, c, dan/atau d menunjukkan berbeda nyata terhadap genotipe pembanding Bioguma 1 (a), Bioguma 3 (b), Kawali (c), dan/atau Numbu (d) menurut uji Dunnett pada taraf 5\%.

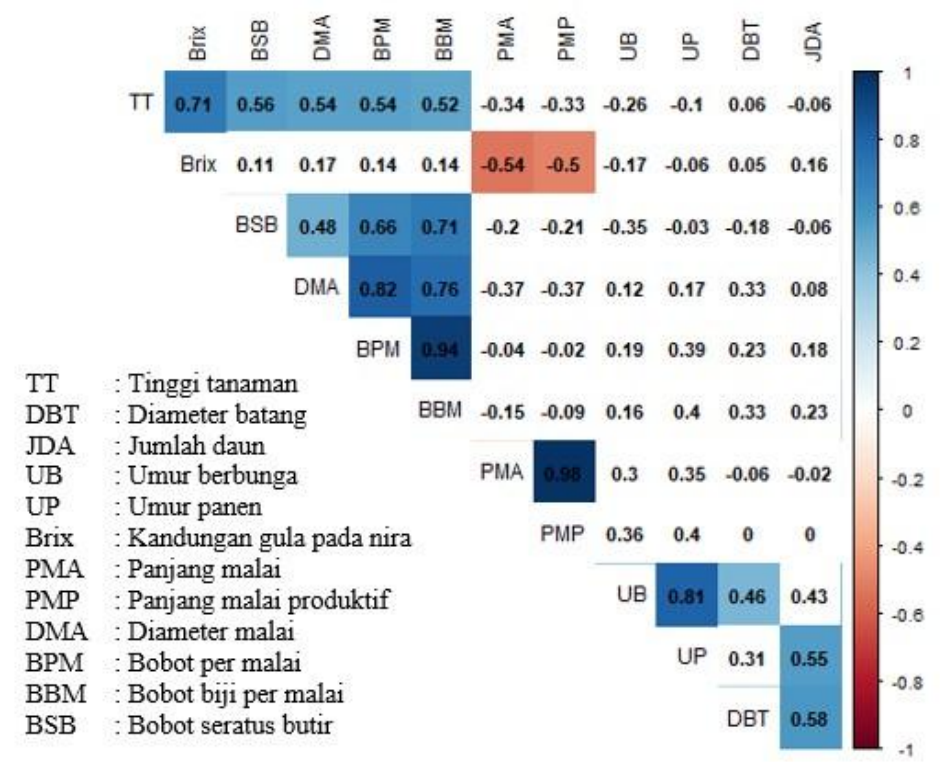

Gambar 1. Koefisien korelasi Pearson antar berbagai karakter galur-galur sorgum multiguna IPB

\section{KESIMPULAN}

Karakter hasil nilai Brix pada nira batang dan bobot biji per malai serta komponen hasil sorgum sangat dipengaruhi oleh genotipe, lingkungan, dan interaksi genotipe $\mathrm{x}$ lingkungan. Sorgum yang tinggi cenderung menghasilkan bobot biji per malai dan nilai Brix pada nira batang yang tinggi. Galur PI 150/N-043-16-5-5-P dan PI 150/K-19-62-B merupakan kandidat galur multiguna dengan tinggi tanaman, bobot biji per malai dan nilai Brix yang tinggi dibanding genotipe lain setara varietas Bioguma 1, Bioguma 3, dan Numbu pada dua musim tanam yang berbeda. 


\section{UCAPAN TERIMA KASIH}

Terima kasih disampaikan kepada Direktorat Riset dan Pengabdian Masyarakat, Direktorat Jenderal Penguatan Riset dan Pengembangan, Kementerian Riset, Teknologi, dan Pendidikan Tinggi yang telah mendanai penelitian ini melalui pendanaan Penelitian Kompetitif Nasional, skema Penelitian Pascasarjana (PPS), Penelitian Tesis Magister (PTM) dengan judul Potensi Hasil dan Kualitas Biji Ratun Galur-Galur Harapan Sorgum IPB pada tahun 2020.

\section{DAFTAR PUSTAKA}

Admas, S., K. Tesfaye. 2017. Genotype-by-environment interaction and yield stability analysis in sorghum (Sorghum bicolor (L.) Moench) genotypes in North Shewa, Ethiopia. Acta Univ. Sapientiae Agric. Environ. 9:82-94.

Amare, K., H. Zeleke, G. Bultosa. 2015. Variability for yield , yield related traits and association among traits of sorghum (Sorghum Bicolor ( L .) Moench) varieties in Wollo, Ethiopia. J. Plant Breed. Crop Sci. 7:125133.

[Balitbangtan] Badan Penelitian dan Pengembangan Pertanian. 2019. Balitbangtan Hasilkan Varietas Unggul Baru Sorgum Bioguma, ini Kelebihannya. http://www.litbang.pertanian.go.id/infoteknologi/ 3573 [09 Oktober 2020].

[BPTP-Bali] Balai Pengkajian Teknologi Pertanian Bali. 2019. Pasca panen dan pengolahan nira sorgum menjadi gula cair. [diakses 2021 Feb 23]. http:// bali.litbang.pertanian.go.id/ind/index.php/infoteknologi/965-pasca-pa nen-dan-pengolahan-nirasorgum-menjadi-gula-cair [23 Februari 2021].

Carcedo, A.J.P., P.A. Pardo, B.L. Gambin. 2017. Secondary traits explaining sorghum genotype by environment interactions for grain yield. Crop Pasture Sci. 68:599608 .

Datta, M.S., A. Poshadri, P. Srinivasa Rao, C.H. Ravinder Reddy, B.V.S. Reddy. 2012. Innovative use of sweet sorghum juice in the beverage industry. IFRJ. 19:1361-1366.

Delgado, I.D., F.M.A. Gonçalves, R.A. da C. Parrella, F.M.R. de Castro, J.A.R. Nunes. 2019. Genotype by environment interaction and adaptability of photoperiod-sensitive biomass sorghum hybrids. Bragantia 78:509-521.

Erickson, J., Z. Helsel, K. Woodard, J.M.B. Vendramini, Y. Wang, L.E. Sollenberger, R.A. Gilbert. 2011.
Planting date affects biomass and Brix of sweet sorghum grown for biofuel across Florida. Agron J. 103:1827-1833.

Hamidou, M., O. Souleymane, M.N. Ba, E.Y. Danquah, I. Kapran, V. Gracen, K. Ofori. 2018. Identification of stable genotypes and genotype by environment interaction for grain yield in sorghum (Sorghum bicolor L. Moench). Plant Genet. Resour-C 1-6.

Hastini, T., W.B. Suwarno, M. Ghulamahdi, H. Aswidinnoor. 2020. Interaksi genotipe $\times$ musim karakter percabangan malai tiga genotipe padi sawah. J. Agron. Indonesia 48:1-7.

Holou, R.A.Y., G. Stevens. 2012. Juice, sugar, and bagasse response of sweet sorghum (Sorghum bicolor (L.) Moench cv. M81E) to $\mathrm{N}$ fertilization and soil type. GCB Bioenergy 4:302-310.

Kerwin, R.E., J. Feusier, A. Muok, C. Lin, B. Larson, D. Copeland, J.A. Corwin, J. Matthew, M.J Rubin, M. Francisco, B. Li, B. Joseph, C. Weinig, D.J. Kliebenstein. 2017. Epistasis $\mathrm{x}$ environment interactions among Arabidopsis thaliana glucosinolate genes impact complex traits and fitness in the field. New Phytol. 215:1249-1263.

Lestari, E.G., I.S. Dewi, A. Nur, R. Yunita, Mastur. 2019. Genetic $\mathrm{x}$ environment interaction on agronomic characters and yield components of sweet sorghum (Sorghum bicolor) mutant strain. Biodiversitas 20:3705-3714.

Makanda, I. 2017. Development of dual purpose sorghum: correlation and path-coefficient analysis of grain yield and stem sugar traits. African Crop Sci. J. 25:263-275.

Morey, S.R., Y. Hashida, R. Ohsugi, J. Yamagishi, N. Aoki. 2018. Evaluation of performance of sorghum varieties grown in Tokyo for sugar accumulation and its correlation with vacuolar invertase genes SbInv1 and SbInv2. Plant Prod. Sci. 21:328-338.

Ndiaye, M., M. Adam, K. K. Ganyo, A. Guissé, N. Cissé, B. Muller. 2019. Genotype-environment interaction: trade-offs between the agronomic performance and stability of dual-purpose sorghum (Sorghum bicolor L. Moench) genotypes in Senegal. Agronomy 9:867.

[NIN] National Institute of Nutrition. 2017. Indian Food Composition Tables. T. Longvah, R. Ananthan, K. Bhaskarachary, K. Venkaiah (Eds.). National Institute of Nutrition, Telangana, IN. 
Oyier, M.O., J.O. Owuoche, M.E. Oyoo, E. Cheruiyot, B. Mulianga, J. Rono. 2017. Effect of harvesting stage on sweet sorghum (Sorghum bicolor L.) genotypes in Western Kenya. Sci. World J. 2017:1-10.

Rifka, D. Wirnas, Trikoesoemaningtyas. 2020. Genotype by environment interaction affecting leaf rust resistance in sorghum. SABRAO J. Breed. Genet. 52:75-90.

Rono, J.K., E.K. Cheruiyot, J.O. Othira, V.W. Njuguna, J.K. Macharia, J. Owuoche, M. Oyier, A.M. Kange. 2016. Adaptability and stability study of selected sweet sorghum genotypes for ethanol production under different environments using AMMI analysis and GGE biplots. Sci World J. 2016:1-14.

Rono, J.K., E.K. Cheruiyot, J.O. Othira, V.W. Njuguna. 2018. Cane yield and juice volume determine ethanol yield in sweet sorghum (Sorghum bicolor L. Moench). Int. J. Appl. Sci. 1:p29.

Shukla, S., T.J. Felderhoff, A. Saballos, W. Vermerris. 2017. The relationship between plant height and sugar accumulation in the stems of sweet sorghum (Sorghum bicolor (L.) Moench). Field Crops Res. 203:181-191.

Subagio, H., M. Aqil. 2014. Perakitan dan pengembangan varietas unggul sorgum untuk pangan, pakan, dan boenergi. Iptek Tanaman Pangan 9:39-50.

Trikoesoemaningtyas, D. Wirnas, D. Sopandie, T. Tesso. 2015. Genotypes x environment interaction effect on nutritional quality of sorghum lines in Indonesia. Ekin J. Crop Breed. Gen. 1-2:26-31.

Trikoesoemaningtyas, D. Wirnas, E.L. Saragih, E.P. Rini, M. Sari, S. Marwiyah, D. Sopandie. 2017. Kendali genetik karakter morfologi dan agronomi pada tiga populasi sorgum (Sorghum bicolor (L.) Moench). J. Agron. Indonesia 45:285-291.

de Vos, M.G.J., F.J. Poelwijk, N. Battich, J.D.T. Ndika, S.J. Tans. 2013. Environmental dependence of genetic constraint. PLoS Genet. 9:1-8. 